\title{
Special Issue: VII Congrés Català de Comptabilitat i Direcció
}

\author{
Joaquim Rabaseda i Tarrés (iD \\ President of the Agrupació de Professors de Comptabilitat i Control \& Member of Board of Directors of the ACCID (Spain) \\ joaquim.rabaseda@udg.edu
}

Received February, 2018

Accepted February, 2018

As is now tradition, we have accepted the invitation of the journal Intangible Capital to publish the most important works presented in the sessions held at the professional and academic seminar organized by the Associació Catalana de Comptabilitat i Direcció (ACCID).

In this case, a total of 13 works have been selected, all original, which were presented at the 7 th Congrés Català de Comptabilitat i Direcció, held in Barcelona on June 8-9, 2017.

The articles that follow cover different topics and are contributed by authors of different origins, from beyond the borders of Catalonia and Spain. In all cases, they are works presented by more than one author, which underscores that they are the product of a collaborative activity.

Different methodologies can also be found, used according to the intended purpose in each case.

The first work is dedicated to the study of the existing literature on the topic of sustainability and relevant indicators for business managers. It was backed by the application of different work sessions, making special reference to the relations between clients and suppliers in the water sector.

The second work is a study of the short-term financial problem through a formal theoretical analysis of new ratios.

The third work concerns the strategies in the area of social economics, through the study of the data published on the cooperatives created in Barcelona in the period 2008-2013.

The fourth is a comparative study between Spanish and German cookie manufacturers, in terms of basically size and the number of employees, based on the corresponding databases.

The fifth work reviews the evolution of how the HRO method was applied in Spanish companies between the financial years 1999 and 2014. The information has been obtained from responses on questionnaires sent to different companies.

The sixth seeks to identify the key factors for success in the Spanish hotel sector, based on the study of the existing literature on the topic.

The seventh concerns the theoretical construction underlying the financial and operational link between companies in the beer industry and their competitive environment, based on the study of 214 industries in 12 European economies. 
The eighth shows us what IQNet SR10 certification means for companies through answers on a survey administered to a single company. A comparison is made of its situation before and after certification, showing the added value that this has meant.

The ninth attempts to identify the impact and predictability of the financial, accounting and industrial factors and determine the difference in the resulting prediction between producers and retailers by applying a regression model to newly-established industries in Spain.

The tenth analyzes the trajectory of the $\mathrm{ABC}$ model through the study of articles published in specialized journals on the topic.

The eleventh work attempts to determine the predictive capacity of Altman's Z-score models in bankruptcy situations in the Spanish setting through the application of this model and the analysis of the database from the 2005-2015 time period.

The twelfth is dedicated to examining the financial health of Spanish hospital companies by studying their financial statements for the 2008-2015 period. It also shows the variables that explain its profitability in order for survival and the proper management of its assets in a period of technological revolution and austerity.

And finally, the thirteenth work identifies the advantages and contributions derived from the implementation of the balanced scorecard, presenting the conclusions obtained from a systematic review of the bibliography published in specialized journals.

We trust that all the works presented in this issue of the journal Intangible Capital constitute a positive contribution to the field of Accounting and Business Administration. We also hope that they give the reader a good idea of the level of the different sessions held at the latest ACCID conference.

Intangible Capital, 2018 (www.intangiblecapital.org)

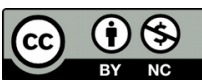

Article's contents are provided on an Attribution-Non Commercial 4.0 Creative commons International License. Readers are allowed to copy, distribute and communicate article's contents, provided the author's and Intangible Capital's names are included. It must not be used for commercial purposes. To see the complete license contents, please visit https://creativecommons.org/licenses/by-nc/4.0/. 